\title{
DIRASAH
}

Volume 2, Number 1, Februari 2019

p-ISSN: 2615-0212 | e-ISSN: 2621-2838

https://ejournal.iaifa.ac.id/index.php/dirasah

\begin{tabular}{|c|c|c|}
\hline Accepted: & Revised: & Published: \\
November 2018 & Januari 2019 & Februari 2019 \\
\hline
\end{tabular}

\section{Upaya Orang Tua dalam Memotivasi Kesungguhan Belajar Anak di Desa Bulusari Tarokan Kabupaten Kediri}

\author{
Doni Saputra \\ Institut Agama Islam Faqih Asy'ari Kediri, Indonesia \\ e-mail:donitwo45@gmail.com
}

\begin{abstract}
This research is in the background by the importance of parents' role as the first and foremost educator for the child to motivate their children in order to increase the seriousness of learning. When children learn should always get attention and guidance from parents. Parents must meet the children's learning needs and always give motivation, otherwise it will be difficult to familiarize the child to learn this research using a qualitative approach that has the characteristics of: natural background And researchers as a key source, and research is descriptive. The results of the study after the analysis, namely: (1) Children's study pattern at home in Bulusari village, Tarokan District of Kediri regency of each child varies, some who like learning in a quiet or silent condition, some are happy to learn While watching TV or listening to the song. Children's learning patterns in this village use two approaches that are self-learning (individual) and with teachers looking for tutoring and learning guidance. (2) The motivational forms of the family so that the children learn vigorous is to give examples to the child, because the child has the data to emulate the good. (3) Forms of motivation given by parents to foster children's learning spirit is to provide complete learning facilities, giving gifts or rewards, creating conducive atmosphere and learning conditions so that children can learn and punishment for a child who does not want to learn and lazy to learn and the child who dropped his learning achievement.
\end{abstract}

Keywords: Parents' Efforts, Motivation, Learning 


\section{Pendahuluan}

Keluarga merupakan unit terkecil dari lingkungan. Di dalam sebuah keluarga seseorang pertama kali berinteraksi dengan sesama manusia. Di dalam keluarga terdapat anggota (atau komponen) yang satu sama lain saling bertalian darah yakni; ayah, ibu, anak. Ayah dan Ibu atau biasa disebut orang tua adalah komponen yang terpenting dalam keluarga, yang mana atas karunia-Nya kedua orang tua akan melahirkan generasi yang baru yakni "anak".

Seorang anak yang dilahirkan di dunia telah dibekali Fitrah Ketuhanan oleh Allah SWT. "Tidaklah anak yang dilahirkan kecuali membawa fitrah (kecenderungan untuk percaya kepada Allah), maka kedua orang tuanyalah yang menjadikan anak tersebut beragama Yahudi, Nasrani, ataupun Majusi” (alHadist). Jika seorang anak mendapatkan pendidikan agama dengan baik, maka mereka akan tumbuh menjadi manusia yang ta'at beragama pula.

Begitu pula jika kita tinjau dari ilmu jiwa agama, seperti yang dikutip oleh Ahmad Patoni dalam bukunya Metodologi Pendidikan Agama Islam. Terdapat beberapa penyelidikannya; dalam jiwa anak semenjak kecil sudah tumbuh perasaan beragama, kemudian akan berkembang sesuai dengan pengaruh lingkungannya. ${ }^{1}$

Dari uraian di atas tampaklah jelas bahwasanya manusia sejak dalam kandungan telah memiliki pendidikan Hablumminallah, sedangkan Hablumminannas-nya dikembangkan dalam keluarga oleh orang tua masingmasing. Kedua orang tua membawa dampak yang sangat signifikan terhadap perkembangan keagamaan yang dibawa anak sejak lahir.

Orang tua yang memiliki pendidikan agama yang luas dan sangat peduli dengan pendidikan pastilah akan mengarahkan, membimbing, dan memotivasi anaknya untuk mendalami ilmu-ilmu agama. Salah satu usaha-usaha orang tua tersebut antara lain yakni les atau bimbingan belajar baik secara kelompok atau privat.

Bimbingan belajar di sini diharapkan agar anak mampu mengatasi kesulitan-kesulitan dalam belajar di sekolah, di TPQ maupun di lembaga pendidikan berjenjang lainnya. Selain itu, ada cara lain orang tua memotivasi anak agar semangat dalam belajar, yakni dengan memberikan reward (hadiah)

\footnotetext{
${ }^{1}$ Ahmad Patoni, Metodologi Pendidikan Agama Islam (Jakarta: Bina Ilmu, 2004), 22.
}

Dirasah, Vol. 2, No. 1, Februari 2019 
jika seorang anak mendapat nilai-nilai tinggi (prestasi) menang dalam olimpiade, menang dalam pertandingan olahraga.

Namun demikian ada juga orang tua yang memberikan motivasi secara lengkap seperti menitipkan anak dalam lembaga belajar privat, memberikan fasilitas-fasilitas yang dibutuhkan seorang anak dalam belajar (seperti buku tulis, buku gambar, alat tulis, alat gambar, komputer, piano, gitar, papan tulis). Selain itu, juga tidak lupa untuk mengontrol belajar dan tugas anak serta mengasih hadiah kepada anak-anak mereka yang berhasil dalam meraih prestasi atau nilai yang memuaskan.

Pemberian motivasi oleh orang tua sangat penting dalam menumbuhkan motivasi, minat, dan semangat dalam belajar. Motivasi orang tua bisa diberikan melalui bentuk kasih sayang mereka, nasehat-nasehat dan yang cukup penting adalah fasilitas seperti alat belajar yang lengkap, ruang belajar yang kondusif demi kenyamanan anak dalam belajar.

Berangkat dari uraian-uraian di atas, maka peneliti tertarik untuk mengadakan penelitian yang berjudul "Studi Tentang Upaya Orang Tua Memotivasi Kesungguhan Belajar Anak Di Desa Bulusari Kecamatan Tarokan Kabupaten Kediri)". Dengan tujuan penelitian adalah: (1) untuk mengetahui pola belajar anak saat berada di rumah di Desa Bulusari Kecamatan Tarokan Kabupaten Kediri; (2) Untuk mengetahui cara keluarga memotivasi anak di Desa Bulusari Kecamatan Tarokan Kabupaten Kediri; (3) untuk mengetahui upaya orang tua memotivasi anak agar memiliki kesungguhan belajar di Desa Bulusari Kecamatan Tarokan Kabupaten Kediri.

\section{Metode Penelitian}

\section{Jenis penelitian}

Metode penelitian merupakan suatu cara yang dilakukan untuk menentukan atau menggali sesuatu yang telah ada untuk kemudian diuji kebenarannya yang mungkin masih diragukan. Oleh karena itu seorang peneliti diharuskan dapat memilih dan menentukan metode yang tepat dan fleksibel guna mencapai tujuannya. Terkait dengan jenis pendekatan penelitian yang ditentukan, penelitian ini menggunakan pendekatan berparadigma deskriptif-kualitatif. Penelitian kualitatif bersifat deskriptif, yaitu data yang terkumpul berbentuk kata - kata, gambar bukan angka - angka. Kalaupun ada angka-angka, sifatnya hanya 
sebagai penunjang. Data yang diperoleh meliputi transkrip interviu, catatan lapangan, foto, dokumen pribadi dan lain-lain. ${ }^{2}$

\section{Teknik pengumpulan data}

\section{Wawancara}

Interview (wawancara) merupakan cara pengumpulan data dengan jalan tanya-jawab sepihak yang dikerjakan dengan sistematik dan berlandaskan kepada tujuan penelitian. ${ }^{3}$ Wawancara ini dilakukan secara mendalam, karena bertujuan menemukan pengalaman-pengalaman informan dari topik tertentu atau situasi spesifik yang dikaji.

Peneliti menerapkan jenis pembicaraan informal, pertanyaan yang diajukan muncul secara spontanitas. Pembicaraan dimulai dari segi umum menuju yang khusus. Peneliti mengajukan pertanyaan yang bebas kepada subjek menuju fokus penelitian. Adapun hubungan antara peneliti dengan subjek yang diwawancarai adalah dalam suasana biasa dalam kehidupan sehari-hari saja, sehingga tidak terlihat kaku dan menakutkan.

2. Observasi

Dalam sebuah penelitian, observasi menjadi bagian hal terpenting yang harus dilakukan oleh peneliti. Sebab dengan observasi keadaan subjek maupun objek penelitian dapat dilihat dan dirasakan langsung oleh seorang peneliti. Menurut Moh. Nazir, observasi diartikan sebagai "pengambilan data dengan menggunakan mata tanpa pertolongan alat standar lain untuk keperluan tersebut". 4

3. Dokumentasi

Arikunto mengatakan bahwa metode dokumentasi adalah mencari data mengenai hal-hal atau variabel yang berupa catatan, transkrip, buku, surat kabar, majalah, prasasti, notulen, rapat, agenda dan sebagainya. ${ }^{5}$

\section{Analisis data}

Analisis data yang dipakai dalam penelitian ini adalah analisis data interaktif (interactive model) terdiri dari tiga alur kegiatan yang terjadi secara

\footnotetext{
${ }^{2}$ Sudarwan Danim, Menjadi Peneliti Kualitatif (Bandung: CV Pustaka Setia, 2002), 51.

${ }^{3}$ Marzuki, Metodologi Riset (Yogyakarta: BPFE UII Yogyakarta, 2001), 62.

${ }^{4}$ Moh. Nazir, Metodologi Penelitian, (Jakarta: Ghalia Indonesia, 1988), 212.

${ }^{5}$ Suharsimi Arikunto, Prosedur Penelitian Pendekatan Praktek (Jakarta: Rineka Cipta, 2006), 231.
} 
bersamaan, yaitu: (1) reduksi data (data reduction), (2) penyajian data (data display), dan (3) penarikan kesimpulan/ verivikasi (conclution drawing/ verification). ${ }^{6}$

\section{Landasan Teoritis}

\section{Tinjauan tentang keluarga}

Keluarga dalam Kamus Pintar Bahasa Indonesia "keluarga mempunyai arti terdiri dari bapak, ibu, dengan anak-anaknya, seisi rumah yang menjadi tanggungannya, batih, saudara kaum kerabat, satuan kekerabatan yang sangat mendasar dalam masyarakat". ${ }^{7}$

Dari pendapat di atas dapat diambil pengertian bahwa yang dimaksud dengan keluarga adalah kelompok masyarakat terkecil yang di satukan melalui ikatan-ikatan perkawinan yang menghasilkan peranan-peranan sosial bagi anggotanya yang umumnya terdiri dari ayah, ibu dengan atau tanpa anak, baik anaknya sendiri atau adopsi dan tinggal dalam sebuah rumah tangga.

\section{Tinjauan tentang motivasi}

1. pengertian motivasi

Motivasi berasal dari kata motif. Motif menurut M. Ngalim Purwanto ialah "segala sesuatu yang mendorong seseorang untuk bertindak melakukan sesuatu". ${ }^{8}$ Motivasi dapat dikatakan sebagai daya penggerak dari dalam dan di dalam subyek untuk melakukan aktivitas-aktivitas tertentu demi mencapai suatu tujuan. Berawal dari kata motif itu, maka motivasi dapat diartikan sebagai daya penggerak yang telah menjadi aktif. Apa saja yang diperbuat manusia yang penting maupun yang kurang penting, yang berbahaya maupun yang tidak mengandung risiko, selalu ada motivasinya.

2. bentuk-bentuk motivasi

a. motivasi intrinsik

Motivasi intrinsik adalah "motivasi yang berasal dari dalam diri anak sendiri". 9 Suatu kegiatan atau aktivitas yang dimulai dan diteruskan berdasarkan penghayatan suatu kebutuhan dan dorongan yang secara

\footnotetext{
${ }^{6}$ Huberman A.Mikel \& Miles M.B, Qualitative Data Analisis (Beverly Hills: SAGE Publication, Inc, 1992), 16-21.

${ }^{7}$ Hamzah Ahmad dan Ananda Santoso, Kamus Pintar Bahasa Indonesia (Surabaya: Fajar Mulia, 1996), 196.

${ }^{8}$ M. Ngalim Purwanto, Psikologi Pendidikan (Bandung: PT. Remaja Rosdakarya, 2004), 60.

${ }^{9}$ Syaiful Bahri Djamarah, Psikologi Belajar (Jakarta: Rineka Cipta, 2002), 126.
} 
mutlak berkaitan dengan aktivitas belajar. Dorongan ini datang dari "hati sanubari". ${ }^{10}$

b. motivasi ekstrinsik

Motivasi ekstrinsik adalah "motivasi atau tenaga-tenaga pendorong yang berasal dari luar diri anak". ${ }^{11}$ Motivasi ekstrinsik sebagai motivasi yang dihasilkan di luar perbuatan itu sendiri misalnya dorongan yang datang dari orang tua, guru, teman-teman dan anggota masyarakat yang berupa hadiah, reward, pujian, penghargaan maupun hukuman.

3. motivasi menurut konsep Islam

Menurut Mujib dan Dzakir, teknik-teknik motivasi dalam al Qur'an mencakup tiga bentuk, yaitu: ${ }^{12}$

a. janji dan ancaman

Al-qur'an menjanjikan pahala yang akan diperoleh orang-orang beriman dalam surga, dan ancaman yang akan menimpa orang-orang kafir dalam neraka. Janji dan ancaman ini menimbulkan harapan dan rasa takut yang merupakan jaminan bagi tumbuhnya dorongan yang kuat bagi diri kaum muslimin untuk melakukan amal yang baik selama hidup di dunia, termasuk belajar.

b. kisah

Kisah yaitu menyajikan berbagai peristiwa, kejadian dan pribadi yang dapat menarik perhatian menimbulkan daya tarik bagi pendengarnya untuk mengikutinya, dan membangkitkan berbagai kesan dan perasaan yang membuat mereka terlibat secara psikis serta terpengaruh secara emosional.

c. pemanfaatan kisah penting

Menggunakan beberapa peristiwa atau persoalan penting yang terjadi yang bisa menggerakkan emosi, menggugah perhatian dan menyibukkan pikiran. Al-qur'an menggunakan peristiwa-peristiwa penting yang dialami kaum muslimin sebagai suri teladan yang baik yang berguna dalam kehidupan mereka. Hal ini membuat mereka lebih siap dan menerima untuk mempelajari dan menguasai keteladanan tersebut.

${ }^{10}$ M. Dalyono, Psikologi Pendidikan (Jakarta: PT Asdi Mahasatya, 2005), 57

${ }^{11}$ Ibid.

12 Nyayu Khodijah, Psikologi Pendidikan (Jakarta: Raja Grafindo persada, 2014), 161.

Dirasah, Vol. 2, No. 1, Februari 2019 


\section{Tinjauan tentang belajar}

1. pengertian belajar

Belajar merupakan suatu bentuk perubahan tingkah laku yang terjadi pada seseorang. Berikut akan dijelaskan definisi belajar yang dikemukakan oleh para ahli.

a. Belajar menurut Witherington, dalam bukunya Education Psychology, sebagaimana dikutip Purwanto, adalah suatu perubahan di dalam kepribadian yang menyatakan diri sebagai pola baru dari pada reaksi yang berupa kecakapan, sikap, kebiasaan, kepandaian, atau suatu pengertian". ${ }^{13}$

b. Abin Syamsuddin Makmun, mengemukakan bahwa belajar adalah "Suatu proses perubahan perilaku atau pribadi seseorang berdasarkan praktik atau pengalaman tertentu". ${ }^{14}$

2. unsur-unsur belajar

Unsur-unsur belajar sangat diperlukan dalam proses pendidikan. Terutama bagi siswa dan guru itu sendiri. Cronbach dalam Nana Syaodih Sukmadinata mengemukakan adanya tujuh unsur utama dalam proses belajar, yaitu sebagai berikut: Tujuan, Kesiapan, Situasi, Interpretasi, Konsekuensi, dan Reaksi terhadap kegagalan.

3. faktor-faktor yang mempengaruhi dalam belajar

Faktor-faktor yang mempengaruhi belajar, secara simpel dibagi tiga macam yaitu: yaitu faktor individual, sosial dan instrumental. Berikut penjelasan terkait ketiga faktor tersebut: ${ }^{15}$

a. faktor individual

Faktor individual dibagi menjadi enam yaitu: faktor fisiologis, psikologis, sikap siswa, bakat belajar, minat siswa, motivasi siswa.

b. faktor sosial

Seperti halnya faktor individual, faktor sosial juga memiliki dua macam faktor yaitu, faktor lingkungan alami dan faktor lingkungan sosial. ${ }^{16}$

\footnotetext{
${ }^{13}$ Ngalim Purwanto, Psikologi Pendidikan (Bandung: Remaja Rosdakarya, 1986), 86.

${ }^{14}$ Abin Syamsuddin Makmun, Psikologi Kependidikan: Perangkat Sistem Pengajaran Modul, (Bandung: PT. Remaja Rosdakarya, 2005), 157

${ }_{15}$ Mahmud, Psikologi Pendidikan (Bandung: CV. Pustaka Setia, 2010), 93.

${ }^{16}$ Syaiful Bahri Djamarah, psikologi belajar., 145.
} 
c. faktor instrumental

Dalam instrumental ini ada beberapa hal yang harus diperhatikan, yaitu: kurikulum apa yang di pakai, program bagaimana yang di jalankan, sarana dan prasarana apa yang harus di penuhi, guru/ tenaga pendidik yang seperti apa yang harus ada sehingga murid/ siswa nyaman dan dapat belajar dengan tenang. 17

4. strategi belajar efektif dan efisien

Belajar yang efektif menurut beberapa tokoh psikologi di antaranya Winkel yang dikutip oleh Rifa Hidayah adalah "cara belajar yang teratur, tuntas, berkesinambungan dan produktif'. ${ }^{18}$ Kebiasaan belajar yang efektif dapat dilakukan di manapun, baik di rumah maupun di sekolah atau LBB dan les privat/ home schooling:

a. belajar di rumah.

Mengembangkan kebiasaan belajar yang efektif di rumah, dapat ditempuh sebagai berikut: (a) membiasakan belajar sesuai dengan jadwal pembagian waktu sehari-hari yang telah dibuat di rumah, (b) membiasakan mengulang pelajaran yang telah diberikan guru, termasuk mengerjakan tugas-tugas guru, seperti PR dan tugas belajar lainnya, (c) tingkatkan ketelitian dan keseriusan dalam belajar, (d) meminta bantuan orang tua, kakak atau teman yang diperkirakan mampu membantu menyelesaikan tugas-tugas sekolah atau pekerjaan rumah.

b. Lembaga Bimbingan Belajar (LBB) formal dan non-formal

Fungsi utama dari bimbingan adalah membantu murid dalam masalah-masalah pribadi dan sosial yang berhubungan dengan pendidikan dan pengajaran atau penempatan dan juga menjadi perantara dari siswa dalam hubungannya dengan guru maupun tenaga administrasi. ${ }^{19}$

c. les privat/ home shcooling

Secara etimologis, home schooling adalah sekolah yang diadakan di rumah. Meski disebut home schooling, tidak berarti anak terus menerus belajar di rumah, tetapi anak-anak bisa belajar di mana saja dan kapan saja

\footnotetext{
${ }^{17}$ Nini Subini, Psikologi Pembelajaran (Yogyakarta: Mentari Pustaka, 2012), 85.

${ }^{18}$ Rifa Hidayah, Psikologi Pendidikan (Malang: UIN Malang Press, 2006), 103-104.

${ }^{19}$ Abu Ahmadi dan Widodo Supriyono, Pskologi Belajar (Jakarta: Rineka Cipta, 2004), 72.
} 
asal situasi dan kondisinya benar-benar nyaman dan menyenangkan seperti layaknya berada di rumah. Home schooling lebih mengacu pada kompetensi praktis hubungan antara ketertarikan dan hoby individu. Serta fleksibilitas metode belajar mengajar tidak terbelenggu oleh dimensi ruang dan waktu secara formal dan dapat menjamin tingkat kompetensi terealisasi dengan baik.

d. belajar di sekolah.

Kebiasaan yang efektif di sekolah dapat ditempuh, antara lain sebagai berikut (a) membiasakan datang ke sekolah tepat waktu, (b) membiasakan mempersiapkan alat-alat tulis secara lengkap dan mengikuti pelajaran dari guru, (c) membiasakan memusatkan perhatian dan menekuni setiap materi pelajaran yang disampaikan guru di kelas, (d) beranikan bertanya pada guru jika ada materi yang kurang dipahami. ${ }^{20}$

Agar lebih detail, berikut kami jabarkan cara belajar yang efektif dan efisien.

a. bimbingan

Seperti kita ketahui, belajar itu sangat kompleks. Belum diketahui segala seluk beluknya. Hasil belajar dipengaruhi oleh banyak faktor. Kecakapan dan ketangkasan belajar berbeda secara individual. Walaupun demikian kita dapat membantu siswa dengan memberi petunjuk-petunjuk umum tentang cara-cara belajar yang efisien. Ini tidak berarti bahwa mengenal petunjuk-petunjuk itu dengan sendirinya akan menjamin sukses siswa. Sukses hanya akan tercapai berkat usaha keras. Tanpa usaha keras mustahil memperoleh kesuksesan.

Di samping memberi petunjuk-petunjuk tentang cara-cara belajar, baik pula siswa diawasi dan dibimbing sewaktu mereka belajar. Hasilnya lebih baik lagi kalau cara-cara belajar dipraktikkan dalam tiap pelajaran yang diberikan. ${ }^{21}$

b. kondisi dan strategi belajar

Belajar yang efektif dapat membantu siswa untuk meningkatkan kemampuan yang diharapkan sesuai dengan tujuan instruksional yang ingin dicapai. Untuk meningkatkan cara belajar yang efektif perlu memperhatikan hal berikut ini:

1) kondisi internal

${ }^{20}$ Rifa Hidayah, Psikologi Pendidikan (Malang: UIN Malang Press, 2006), 104-105.

${ }^{21}$ Slamet, Belajar dan Faktor-Faktor yang Mempengaruhi (Jakarta: Rineka Cipta, 2003), 74.

Dirasah, Vol. 2, No. 1, Februari 2019 
Yang dimaksud dengan kondisi internal yaitu kondisi (situasi) yang ada di dalam diri siswa itu sendiri misalnya kesehatannya, keamanannya, ketenteramannya, dan sebagainya. Siswa dapat belajar dengan baik apabila kebutuhan-kebutuhan internalnya dapat dipenuhi.

2) kondisi eksternal

Yang dimaksud dengan kondisi eksternal adalah kondisi yang ada di luar diri pribadi manusia, umpamanya kebersihan rumah, penerangan, serat keadaan lingkungan fisik lain. Untuk dapat belajar efektif diperlukan lingkungan fisik yang baik dan teratur, misalnya: ${ }^{22}$ Ruang belajar harus bersih, tidak ada bau yang mengganggu konsentrasi pikiran, ruangan cukup tenang, tidak gelap yang dapat mengganggu mata serta cukup sarana yang diperlukan untuk belajar, misalnya alat pelajaran, buku-buku dan sebagainya.

3) Strategi belajar

Belajar yang efisien dapat tercapai apabila dapat menggunakan strategi belajar yang tepat. Strategi belajar diperlukan untuk dapat mencapai hasil yang maksimal.

Seseorang yang menyelidiki berbagai buku tentang cara-cara belajar yang baik mengumpulkan berbagai macam petunjuk yang penting seperti berikut ini: ${ }^{23}$ Keadaan jasmani, Keadaan sosial dan emosional, Keadaan lingkungan, Memulai belajar, Membagi pekerjaan, Adakan kontrol, Pupuk sikap optimis, Waktu belajar, Struktur rencana belajar, Kerja keras dan Mempertinggi kecepatan membaca.

c. Metode belajar

Metode adalah cara atau jalan yang harus dilalui untuk mencapai suatu tujuan tertentu. Belajar bertujuan untuk mendapatkan pengetahuan, sikap, kecakapan dan keterampilan, cara-cara yang dipakai itu akan menjadi kebiasaan. Kebiasaan belajar itu akan mempengaruhi belajar, khususnya pembuatan jadwal dan pelaksanaannya. Berikut yang harus dilakukan: ${ }^{24}$

22 Ibid., 74.

23 Ibid., 75.

${ }^{24}$ Ibid., 78.

Dirasah, Vol. 2, No. 1, Februari 2019 
1) pembuatan jadwal dan pelaksanaannya

Jadwal adalah pembagian waktu untuk sejumlah kegiatan yang dilaksanakan oleh setiap harinya. Jadwal juga berpengaruh terhadap belajar. ${ }^{25}$ Agar belajar dapat berjalan dengan baik dan hasilnya memuaskan perlu dilaksanakan dengan teratur dan disiplin. Membaca dan membuat catatan

Membaca besar pengaruhnya terhadap belajar. Hampir sebagian besar kegiatan belajar adalah membaca. Agar dapat belajar degan baik maka perlu membaca dengan baik pula, karena membaca adalah alat belajar.

2) mengulangi bahan pelajaran

Mengulangi besar pengaruhnya dalam belajar, karena dengan adanya pengulangan (review)"bahan yang belum dikuasai serta mudah terlupakan" akan tetap tertanam dalam otak seseorang. ${ }^{26}$

3) konsentrasi

Konsentrasi adalah pemusatan pikiran terhadap suatu hal dengan menyampingkan semua hal lainnya yang tidak berhubungan. Dalam kenyataan seseorang sering mengalami kesulitan untuk berkonsentrasi, hal ini disebabkan karena: kurang minat terhadap mata pelajaran yang dipelajari, terganggu oleh keadaan lingkungan (bising, cuaca buruk, dan lain-lain). ${ }^{27}$

4) mengerjakan tugas

Tugas disini yang dimaksud adalah yang berupa pekerjaan rumah dan tugas yang harus dikerjakan di sekolah. ${ }^{28}$

\section{Tinjauan tentang anak}

Dalam Kamus Umum Bahasa Indonesia, "anak adalah keturunan yang kedua atau manusia yang masih kecil". Pengertian anak ini bersifat secara umum. Untuk lebih mengkhususkan definisi anak, maka definisi anak dapat di tinjau dari beberapa segi, yaitu segi agama, negara, dan psikologis. Anak dalam perspektif Islam adalah amanah dari Tuhan yang harus kita jaga dan lindungi mereka. Anak itu suci dalam keadaan fitrah yang di mana amal baik dan alam buruknya

\footnotetext{
25 Ibid., 79.

${ }^{26}$ Ibid., 80.

27 Ibid., 81.

${ }^{28}$ Ibid., 85.
} 
merupakan cobaan atau ujian dari Tuhan. Sedangkan pandangan hukum positif menurut Konvensi Hak Anak (KHA) mendefinisikan anak sebagai manusia yang umurnya belum mencapai 18 tahun. Sedangkan dalam Undang-undang Perlindungan Anak, mendefinisikan "anak adalah seseorang yang belum berusia 18 (delapan belas) tahun, termasuk anak yang masih dalam kandungan. ${ }^{29}$ Sementara itu, pandangan psikologis, definisi anak dalam psikologis adalah "seseorang yang belum mencapai tingkat kedewasaannya. Bisa berarti seorang individu di antara kelahiran dan masa pubertas, atau seorang individu di antara masa kanak-kanak dan masa pubertas. ${ }^{30}$

Pengertian anak juga mencakup masa anak itu ada. Hal ini untuk menghindari kesalahan mengenai pengertian anak dalam hubungannya dengan orang tua dan pengertian anak itu sendiri setelah menjadi orang tua. Kasiram mengatakan anak adalah makhluk yang sedang dalam taraf perkembangan yang mempunyai perasaan, pikiran, kehendak sendiri, yang semuanya itu merupakan totalitas psikis dan sifat-sifat serta struktur yang berlainan pada tiap-tiap fase perkembangannya. ${ }^{31}$ Hurlock membagi fase-fase perkembangan individu secara lengkap sebagai berikut:

Tabel Fase Perkembangan Anak

\begin{tabular}{cll}
\hline No & \multicolumn{1}{c}{ Nama Tahapan } & \multicolumn{1}{c}{ Waktu } \\
\hline 1 & Prenatal & Conception-280 days \\
\hline 2 & Infancy & 0 -10 to 14 days \\
\hline 3 & Baby Hood & 2 weeks-2 years \\
\hline 4 & Child Hood & 2 years-adobcence \\
\hline 5 & Adolescense & $(13$ (girls)-21 years $)$ \\
& & $(14$ (boys)-21 years $)$ \\
\hline 6 & Adult Hood & $21-25$ years \\
\hline 7 & Midle Age & $25-30$ years \\
\hline 8 & Old Age & 30 ears-death \\
\hline
\end{tabular}

\section{Temuan Penelitian}

\footnotetext{
${ }^{29}$ R. Subekti, Pokok-Pokok Hukum Perdata (Jakarta: PT. Inter Masa, 2003 ), 5.

${ }^{30}$ Kamus Lengkap Psikologis J.P.Chaplin,1999

${ }^{31}$ Supeno H. Kriminalisasi Anak. (Jakarta:PT Gramedia Pustaka Utama 2010), 51
}

Dirasah, Vol. 2, No. 1, Februari 2019 
Data yang diperoleh dari lapangan adalah data hasil observasi dan interview atau wawancara. Dalam hal ini, peneliti tidak mengalami kendala yang berarti untuk menggali informasi.

\section{Pola belajar anak saat berada di rumah}

Perlu diketahui bahwa di desa Bulusari, anak-anak dalam melaksanakan pembelajaran non-formal ada yang belajar secara mandiri (individu) dan individu ditemani orang tua, dan ada juga yang belajar dengan cara mencari les dan Lembaga Bimbingan Belajar (LBB). Hal ini dilakukan untuk menunjang ilmu yang di dapat dari sekolah. Sebagian ada yang kemauan sendiri dan ada juga karena kemauan dari orang tua siswa.

1. Belajar secara mandiri

Perlu kita ketahui, bahwa dalam melaksanakan kegiatan belajar mengajar, baik dalam lingkungan formal atau non-formal pasti terjadi perbedaan yang sangat signifikan. Di mana pola belajar peserta didik saat di sekolah. Peserta didik diwajibkan mengikuti peraturan yang ada. Namun saat peserta didik sudah pulang sekolah, anak-anak akan menggunakan pola belajar menurut mereka sendiri dan bimbingan dari orang tua.

2. Les (Pendidikan luar sekolah)

Selain belajar mandiri (individu), pola belajar sebagian siswa di desa Bulusari juga ikut dalam les di LBB formal dan non-formal. Hal ini mereka lakukan karena untuk menambah wawasan belajar mereka. Selain itu saat belajar di les di LBB, banyak hal-hal yang tidak ditemukan saat belajar di sekolah SD dan MIS yang mereka dapatkan di sini.

\section{Bentuk-bentuk motivasi dalam lingkungan keluarga}

Belajar adalah proses aktif dan dipengaruhi oleh kebutuhan yang terasa oleh diri anak. Untuk itu perlu ditanamkan pada diri anak rasa kebutuhan akan belajar yang merupakan tugas dari orang tua.

Selain orang tua anggota keluarga sangat berperan penting dalam kemajuan belajar anak yang masih sekolah. Anggota keluarga bisa di ambil dari keluarga inti dan keluarga dekat. Keluarga inti seperti halnya ayah, ibu, kakak laki-laki, kakak perempuan dan adik bungsu. Keluarga dekat dapat dikatakan seperti halnya kakek, nenek, paman, dan bibi.

Selain berbagai bentuk motivasi tersebut di atas, masih ada bentuk-bentuk pemberian motivasi yang lain seperti mendampingi anak waktu belajar, selalu mengingatkannya dan melatihnya disiplin dalam mengatur waktu atau juga 
dengan mengikutkan anaknya les atau bimbingan belajar. Hal itu semua dapat menumbuhkan semangat dalam belajar dan menjadikan belajar anak menjadi sungguh-sungguh.

\section{Upaya orang tua memotivasi anak agar memiliki kesungguhan belajar}

Belajar merupakan hal yang dilakukan oleh banyak orang. Di mana belajar dilakukan mulai dari anak-anak sampai sebelum kita mati. Kebutuhan akan belajar merupakan hal yang pokok saat kita ingin menggapai mimpi setinggi mungkin. Untuk itu perlu ditanamkan pada diri anak rasa kebutuhan akan belajar. Mengingat keinginan dan kemampuan setiap anak itu berbeda-beda, maka tugas orang tua harus mengenali setiap keinginan dan kemampuan yang dimiliki seorang anak. Menciptakan lingkungan yang nyaman untuk belajar, memberi hadiah pada anak agar semangat dalam belajar, disiplin untuk terus mengingatkan anak untuk belajar, itu semua merupakan bentuk-bentuk motivasi yang bisa dilakukan oleh orang tua dalam menumbuhkan semangat belajar anak.

Orang tua atau ibu dan ayah memegang peranan yang penting dan sangat berpengaruh atas pendidikan anak-anaknya. Sejak seorang anak dilahirkan ibunya yang selalu ada di sampingnya. Hal ini menunjukkan tanggung jawab setiap orang tua atas kehidupan anak-anak mereka untuk masa kini dan mendatang. Bahkan para orang tua umumnya merasa tanggung jawab atas segalanya dari kelangsungan hidup anak-anak mereka.

Berikut beberapa motivasi yang diberikan orang tua kepada anaknya di desa Bulusari:

\section{Reward (Hadiah)}

Pemberian semangat atau motivasi dari orang tua kepada anaknya dalam upaya menciptakan kesungguhan belajar anak akan berhasil bila pihak orang tua selalu mendampingi anak dalam belajar, atau ketika anak belajar sendiri, orang tua tidak lupa untuk memantaunya. Akan tetapi jangan lupa, bahwa menyuruh anak untuk belajar atau memberikan hadiah sebagai bentuk motivasi kepada anak untuk belajar tetap harus dilakukan. Pemberian motivasi oleh orang tua merupakan sebuah usaha meningkatkan belajar anak yang sekaligus sebagai bentuk kepedulian pada anak atau bentuk kasih sayang dan tanggung jawab orang tua terhadap anak.

2. Punishment (Hukuman) 
Selain hadiah, motivasi dari orang tua yang lain adalah terkait dengan hukuman. Hukuman ini berperan penting ke dapan anak yang kurang disiplin dan malas belajar sehingga prestasi belajar turun drastis.

\section{Pembahasan}

\section{Pola belajar anak saat berada di rumah}

Di desa Bulusari, dalam kesehariannya anak-anak yang tergolong masih berpendidikan sekolah dasar secara tidak langsung juga melakukan hal tersebut. Setiap kali mendapatkan tambahan ilmu dari sekolah atau lembaga pendidikan secara formal dan non-formal berusaha mengaplikasikannya di dalam masyarakat. Hal ini terbukti dengan adanya temuan peneliti terkait dengan ibadah yang dilakukan anak-anak tersebut. Dalam kesehariannya, anak-anak di desa Bulusari kecamatan Tarokan kabupaten kediri secara tidak langsung juga memiliki pola atau metode belajar yang berbeda beda dari anak satu ke anak yang lain.

Seperti halnya dengan pembagian waktu untuk sejumlah kegiatan yang dilaksanakan oleh setiap harinya. Jadwal juga berpengaruh terhadap belajar. Agar belajar dapat berjalan dengan baik dan hasilnya memuaskan perlu dilaksanakan dengan teratur dan disiplin. Berikut cara membuat jadwal yang baik adalah sebagai berikut:

1. Memperhitungkan waktu setiap hari untuk keperluan-keperluan tidur, belajar, makan, mandi, olahraga dan lain-lain.

2. Menyelidiki dan menentukan waktu-waktu yang tersedia setiap hari.

3. Merencanakan penggunaan belajar itu dengan cara menetapkan jenis-jenis mata pelajaran dan urut-urutan yang harus dipelajari.

4. Menyelidiki waktu-waktu mana yang dapat dipergunakan untuk belajar dengan hasil terbaik.

5. Berhematlah dengan waktu, setiap siswa jangan ragu-ragu untuk memulai pekerjaan, termasuk belajar.

Selain itu, faktor terpenting dalam belajar adalah kesehatan. Di mana kesehatan berperan sangat riskan, jika anak sudah sakit maka belajar tidak akan kondusif dan perlu pengobatan. Selain itu banyak faktor-faktor yang mempengaruhi dalam belajar seperti faktor fisiologis, psikologis, sikap siswa, bakat belajar, minat siswa, motivasi siswa.

\section{Bentuk-bentuk motivasi dalam lingkungan keluarga}


Di desa Bulusari, apa yang dikemukakan oleh profesor Soeleman sangat benar dan terjadi. Keluarga sangat berperan penting dalam perkembangan anak. Selain sebagai media education pertama dan sangan urgen, keluarga menjelma sebagai juru selamat anak saat nanti terjun ke dunia sosial yang penuh dengan segala problematiknya.

Selain itu, selain keluarga sebagai media education yang pertama. Keluarga juga merupakan media education seumur hidup. Di mana ini terjadi saat anak di lahirkan sampai anak dewasa dan meninggal dunia. Berikut undang-undang juga mencetuskan pendapatnya.

Sebagaimana di jelaskan dalam Undang-undang Nomor 20 tahun 2003 tentang Sistem Pendidikan Nasional berkenaan dengan pendidikan antara lain dikemukakan sebagai berikut: "pendidikan berlangsung seumur hidup dan dilaksanakan di dalam keluarga, sekolah dan masyarakat karena itu pendidikan merupakan tanggung jawab bersama antara keluarga, masyarakat dan pemerintah". ${ }^{32}$

Anak sangat peka terhadap iklim emosional yang terdapat dalam keluarga. Kehangatan yang terpancar dari seluruh gerakan, ucapan, mimik wajah serta perbuatan orang tua merupakan bumbu pokok dalam pelaksanaan pendidikan anak dalam keluarga.33 Hal ini mengandung implikasi bahwa dalam menghadapi dan bergaul dengan anak, orang tua hendaknya memahami, mampu menangkap dan turut merasakan apa yang dirasakan anak serta bagaimana persepsi anak tentang orang tua dan lingkungan tempat anak tinggal.

Jadi dapat ditarik kesimpulan, jika ingin mendapatkan hasil yang memuaskan terkait dengan pendidikan anak kita. Maka, sebagai orang tua dan keluarga kita harus memberikan contoh yang baik pula terhadap anak dan keluarga kita.

\section{Upaya orang tua memotivasi anak agar memiliki kesungguhan belajar di desa Bulusari}

Seperti kita ketahui, belajar itu sangat kompleks. Belum diketahui segala seluk beluknya. Hasil belajar dipengaruhi oleh banyak faktor. Kecakapan dan ketangkasan belajar berbeda secara individual. Walaupun demikian kita dapat

\footnotetext{
${ }^{32}$ Undang-Undang Republik Indonesia No. 20 Tahun 2003 tentang Sistem Pendidikan Nasional, (Jakarta: PT Armas Duta Jaya, 2003), hlm. 73

${ }^{33}$ Ibid., hlm. 95
}

Dirasah, Vol. 2, No. 1, Februari 2019 
membantu siswa dengan memberi petunjuk-petunjuk umum tentang cara-cara belajar yang efisien. Ini tidak berarti bahwa mengenal petunjuk-petunjuk itu dengan sendirinya akan menjamin sukses siswa. Sukses hanya akan tercapai berkat usaha keras. Tanpa usaha keras mustahil memperoleh kesuksesan.

Selain itu bentuk-bentuk motivasi yang diberikan orang tua untuk menumbuhkan semangat belajar anak adalah dengan memberikan fasilitas belajar yang lengkap, memberikan hadiah atau reward, menciptakan suasana dan kondisi belajar yang kondusif agar anak dapat belajar dengan tenang dan nyaman, dan senantiasa mengingatkan dan mendampingi anak dalam belajar, agar anak merasa diperhatikan dan disayangi orang tuanya.

Kemudian Hukuman merupakan yang paling terakhir diambil apabila teguran dan peringatan belum mampu untuk mencegah anak melakukan pelanggaran- pelanggaran. Dari pengertian di atas, maka dapat disimpulkan bahwa hukuman adalah alat pendidikan yang diharapkan dapat menumbuhkan kedisiplinan dan ketertiban anak didik.

Hukuman yang diberikan oleh orang tua anak di desa Bulusari di antaranya adalah tidak memberikan hadiah yang di janjikan saat anak tidak mau belajar, kemudian ada hukuman fisik yang intinya tidak sampai menyederai anak sehingga anak dapat melaksanakan kewajiban anak yaitu belajar dengan baik dan tekun.

Selain disiplin dibidang pendidikan formal, orang tua anak di desa Bulusari juga mengedepankan pendidikan siswa dibidang agama, di mana anak yang tidak patuh dan kurang konsisten dibidang agama juga akan mendapatkan teguran dan hukuman. Karena orang hidup tidak saja untuk mendapatkan kebahagiaan di dunia saja, tetapi akhiratnya juga perlu diperhitungkan. Sehingga ini juga menjadikan anak baik secara akhlak.

Keterangan hasil penelitian di atas juga sesuai dengan teori motivasi menurut Islam. Menurut Mujib dan Dzakir, berbagai bentuk motivasi yang di kemukakan oleh para psikolog hanya bersifat duniawi dan jangka pendek, juga tidak menyentuh aspek-aspek spiritual dan ilahiyah. Dalam Islam, motivasi diakui berperan penting dalam belajar. ${ }^{34}$

Yang cukup sangat dipegang teguh oleh para muslim adalah Al-qur'an menjanjikan pahala yang akan diperoleh orang-orang beriman dalam surga, dan ancaman yang akan menimpa orang-orang kafir dalam neraka. Janji dan ancaman

${ }^{34}$ Khodijah, nyayu. Psikologi pendidikan (jakarta: pt. Raja grafindo persada, 2014), hal. 161

Dirasah, Vol. 2, No. 1, Februari 2019 
ini menimbulkan harapan dan rasa takut yang merupakan jaminan bagi tumbuhnya dorongan yang kuat bagi diri kaum muslimin untuk melakukan amal yang baik selama hidup di dunia, termasuk belajar.

Secara psikologis akan mendorong orang untuk melakukan hal yang terbaik dan berbuat kebajikan untuk dunia dan akhiratnya. Sehingga nantinya anak akan sukses dunia dan akhirat.

Pemberian semangat atau motivasi dari orang tua kepada anaknya dalam upaya menciptakan kesungguhan belajar anak akan berhasil bila pihak orang tua selalu mendampingi anak dalam belajar, atau ketika anak belajar sendiri, orang tua tidak lupa untuk memantaunya. Kalau suasana belajar dalam rumah sudah tercipta dengan baik maka anak pun dengan senang hati akan belajar tanpa menunggu untuk disuruh atau diiming-imingi hadiah.

Akan tetapi jangan lupa, bahwa menyuruh anak untuk belajar atau memberikan hadiah sebagai bentuk motivasi kepada anak untuk belajar tetap harus dilakukan. Pemberian motivasi oleh orang tua merupakan sebuah usaha meningkatkan belajar anak yang sekaligus sebagai bentuk kepedulian pada anak atau bentuk kasih sayang dan tanggung jawab orang tua terhadap anak.

\section{Penutup}

Berdasarkan uraian penyajian data dan analisis data hasil penelitian, maka dapat disimpulkan sebagai berikut:

\section{Pola belajar anak saat berada di rumah}

Pola belajar anak di rumah di Desa Bulusari Kecamatan Tarokan Kabupaten Kediri dari masing-masing anak berbeda-beda, ada yang menyukai belajar dalam kondisi tenang atau sunyi, ada juga yang senang belajar dengan sambil menonton TV atau mendengarkan lagu. Selain itu, pola belajar anak di desa ini menggunakan dua pendekatan yaitu belajar sendiri (individu) dan dengan mencari guru untuk les dan bimbingan belajar.

\section{Bentuk-bentuk motivasi dalam lingkungan keluarga}

Bentuk-bentuk motivasi dalam lingkungan keluarga yang ada di desa Bulusari kecamatan Tarokan kabupaten kediri adalah dengan memberikan sugesti dan dorongan kepada anak. Selain itu fungsi meniru dari anak terhadap kelakuan dan tindakan orang tua juga berperan peting dalam memberikan dorongan anak untuk belajar. 


\section{Upaya orang tua memotivasi anak agar memiliki kesungguhan belajar}

Bentuk-bentuk motivasi yang diberikan orang tua untuk menumbuhkan semangat belajar anak di Desa Bulusari Kecamatan Tarokan Kabupaten Kediri adalah dengan memberikan fasilitas belajar yang lengkap, memberikan hadiah atau reward, menciptakan suasana dan kondisi belajar yang kondusif agar anak dapat belajar dengan tenang dan nyaman, dan senantiasa mengingatkan dan mendampingi anak dalam belajar, agar anak merasa diperhatikan dan disayangi orang tuanya. Selain itu, bentuk motivasi yang lain dengan memasukkan anak dalam lembaga bimbingan belajar juga bisa menumbuhkan semangat anak dalam belajar.

\section{Daftar Pustaka}

Arikunto, Suharsimi. Manajemen Penelitian. Jakarta: Rineka Cipta. 2003. Rineka. 2006.

. Prosedur Penelitian:Suatu Pendekatan Praktik, Cet.13. Jakarta:

Ary, Donald dkk. Pengantar Penelitian dalam Pendidikan, terj. Arief Furchan. Yogyakarta: Pustaka Pelajar. 2004

Dalyono, M. Psikologi Pendidikan. Jakarta: PT Asdi Mahasatya. 2005.

Dimyati dan Mudjiono. Belajar dan Pembelajaran. Jakarta: Rineka Cipta. 2006.

Djamarah, Syaiful Bahri. Psikologi Belajar. Jakarta: Rineka Cipta. 2002.

Hidayah, Rifa. Psikologi Pendidikan. Malang: UIN Malang Press. 2006.

Khodijah, Nyayu. Psikologi pendidikan. Jakarta: Raja Grafindo Persada. 2014.

Makmun, Abin Syamsuddin. Psikologi Kependidikan: Perangkat Sistem Pengajaran Modul. Bandung: PT. Remaja Rosdakarya. 2005.

Marzuki. Metodologi Riset. Yogyakarta: BPFE UII Yogyakarta. 2001.

Moleong, Lexy J. Metodologi Penelitian Kualitatif. Bandung: PT Remaja Rosdakarya. 2007. 
Mulyana, Dedy. Metodologi Penelitian Kualitatif: Paradigma Baru Ilmu Komunikasi dan Ilmu Sosial Lainnya. Bandung: PT Remaja Rosdakarya. 2003.

Oemar, Hamalik. Proses Belajar Mengajar. Jakarta: PT Bumi Aksara. 2008.

Patoni, Ahmad. Metodologi Pendidikan Agama Islam. Jakarta: Bina Ilmu. 2004.

Purwanto, M. Ngalim. Psikologi Pendidikan, Bandung: PT. Remaja Rosdakarya. 2004.

Slamet. Belajar dan faktor-faktor yang mempengaruhi. Jakarta: PT. Rineka Cipta. 2003.

Subini, Nini. Psikologi Pembelajaran. Yogyakarta: Mentari Pustaka. 2012.

Sugiyono.. Metode Penelitian Kuantitatif Kualitatif Dan $R \& D$. Bandung: Alfabeta. 2008.

Sukardi. Metode Penelitian Pendidikan : Kompetensi dan Prakteknya. Jakarta: Bumi Aksara. 2005.

Sumiyarno. Penelitian Kualitatif: Langkah Operasional. Surabaya: Makalah tidak diterbitkan. 2000.

Syah, Muhibbin. Psikologi Belajar. Jakarta: PT RajaGrafindo Persada. 2006.

Usman, Moh. Uzer. Menjadi Guru Profesional, Bandung: PT. Remaja Rosdakarya, 2005.

Wardiana, Uswah. "Peranan Konsep Diri dalam Meningkatkan Prestasi. 2005.

Wiriaatmaja, Rochiati. Metode Penelitian Tindakan . Bandung: PT. Rosdakarya. 2007. 
Copyright (C 2019 Journal Dirasah: Vol. 2, No. 1, Februari 2019, p-ISSN: 2615-0212, e-ISSN; 2621-2838

Copyright rests with the authors

Copyright of Jurnal Dirasah is the property of Jurnal Dirasah and its content may not be copied or emailed to multiple sites or posted to a listserv without the copyright holder's express written permission. However, users may print, download, or email articles for individual use.

https://ejournal.iaifa.ac.id/index.php/dirasah 